\title{
Depression in Jojo Moyes' Me Before You
}

\section{Rizki Febri Hariani and Sri Wulan}

Universitas Islam Sumatera Utara (UISU), Medan, Indonesia

\section{Abstract}

This paper focuses on two subject matters of depression found in the novel. The subject matters of this study are the symptoms and the causes of the protagonist's depression. Each matter applies different theory. For the analysis, Johnson's and Jiwo's concepts are used. The design of this study is qualitative descriptive method because the data are analyzed by narrative description and interpretation about the story in the novel. The result of this study shows that the protagonist's depression can be seen from the three symptoms which are 1) he feels that no one cares about him, 2) he only thinks about himself or self-centeredness, 3) he always tries to end his life. Those symptoms appear due to two causes; 1) he starts to feel lonely and isolate himself after the accident which makes him disabled; and 2) he gets traumatic after the accident and always tries to commit suicide. Although, he tries to overcome his depression by

Corresponding Author: Rizki Febri Hariani

sriwulan@sastra.uisu.ac.id

Received: 1 July 2019

Accepted: 18 July 2019

Published: 31 July 2019

Publishing services provided by Knowledge E

(c) Rizki Febri Hariani and Sri Wulan. This article is distributed under the terms of the

Commons Attribution License,

which permits unrestricted use and redistribution provided that the original author and source are credited.

Selection and Peer-review under the responsibility of the AICLL 2019 Conference Committee.

\section{Introduction}

Novel, as one of fictional works, necessarily embodies issues and ideas of life experience. Even stories written for entertainment alone are based on an idea or position. The idea will bring the readers into a message. Then the message will make the readers easier to understand the story. The idea or what we called theme sometimes talks about social life. In fact, the literary work reflects the depiction of society, real life or social condition.

In this case the idea that is analyzed is depression. In social life, depression is existed. Some human beings sometimes feel the characteristics of depression in their life. We as human beings sometimes feel depressed of something in our life or at least we run short of hope. Depression may cause someone to feel hopeless and try to do anything, regardless of the danger.

The novel Me Before you, was written by Pauline Sara-Jo Moyes who was born on 4 August 1969 in Maidstone, England. Me Before You released in 5 January 2012. This novel has been filmed with the same title in the United States in June $3^{r d}, 2016$. Me 
Before you is a romantic novel. It gives us insight of life meaning in unique way. It answers question about what kind of life you want and people struggle for ideal life condition. The main characters are Louisa Clark and Will Traynor. But, the analysis focuses on the psychological condition of the protagonist in the novel, especially depression. The protagonist in this novel shows the symptoms of depression due to two causes: social aspect and psychological aspect.

Depression is a state of low mood and aversion to activity that can have a negative effect on one's thoughts, behavior, feelings, world view and physical well-being. Depressed people may feel sad, anxious, empty, hopeless, worried, helpless, worthless, guilty, irritable, hurt, or restless. They may lose interest in activities that experience loss of appetite or overeating, have problems to concentrate, remembering details, or making decisions, and may contemplate or make an attempt to commit suicide. Insomnia, excessive sleeping, fatigue, loss of energy, or aches, pains or digestive problems that are resistant to treatment may come to him.

This topic is chosen because depression is a problem which is commonly faced by people nowadays, and even it can be more serious if it is not be overcome correctly. Depression is a normal reaction to a fairly severe event in life. Someone who is depressed can commit suicide. By learning the novel Me before You by Jojo Moyes we can get not only entertainment but also insight about symptoms, causes and how to overcome depression as depicted in the novel and this is described in this study. Therefore, it is hoped that this study may give contribution to the readers any input about depression so that it can be avoided or cured when it comes.

\section{Literature Review}

Depression is more than just feelings of unhappiness, clinical or major depression is a mood disorder, a medical illness that involves both the body and mind. Depression is excessively sad feeling until it may makes someone think that his life is meaningless.

Depression is usually thought of being a disorder or disturbance in mood. Everyone, at various times in life, feels sad or blue. Sadness or grief is a normal response to death, loss, separation or difficult life events. Depressed people are potentially capable of doing very well on tests of memory abstract thought, but their perceptions about the world and their reactions are askew.

Berstain (1988: 561) states that depression plays a central role in many mood disorders and can range from occasional down periods to episodes severe enough to require hospitalization. Cognitive changes characteristic of depression include thought 
of worthlessness and uselessness, irrational guilt feelings, and ideas that the world is empty and has nothing positive to offer. In severe cases, the person's think may become psychotic. He or she may have delusion (fixed irrational ideas) or hallucinations (hear imaginary voices). Depressive delusions and hallucinations tend to be severely selfblaming. The person may be convinced that he or she has committed a horrible crime or can be tortured by voices making terrible accusation and whispering horrible warning of doom.

Depression can also produce a range of physical change: disturbances of appetite either indifference to food or compulsive overate; problem with sleep; - sleeplessness, commonly sleeping excessively; impairments of digestion and elimination - nausea, heartburn, constipation, fatigue, inability to concentrate, and slowed thinking and moving are also characteristic physical signs

Some people sometimes do not care about what has happened to them even though there are so many problems that cause the people to be depression. They even forget the psychological problem that has happened, as it is said that: depression is psychological disorder characterized by long bouts of severe mood disturbance or excessive relation, which are unconnected with the individual's present situations (Downing-orr, 2013: 26). The depression is a psychological problem that commonly happens to the people. It is kind of mental disease that is caused by anxiety.

Depression is the condition when people are sad, broken hearted, or losing someone or something in their life. Depression gives the bad mental influences for those who feel it (Goodman, 2011: 32). Based on the distinction about the theory of depression, it is clear depression give the mental influence because they face problem in their life. Next, sad and broken heart feeling is identified as the depression characteristics. It can also be identified as someone who lose something or someone.

According to Schwartz and Schwartz (in Robbins quoted by Veranita, 2013), depression is an effective, or mood disorder. It is an illness that immerses its sufferers in a world of self-blame, confusion, and hopelessness. It is an illness of the main and the body. Some could argue depression is a way of coping with life's pressure.

While, Jiwo (2012) explains that depression is an annoyance of psychology or mood that is marked by were characterized by excessive sadness, depressed, discouraged, feeling worthless, felt life was empty and there is no hope, thoughts centered on the failures and mistakes themselves or accuse themselves, and often accompanied envy and suicidal thoughts

Johnson (2018) clarifies depression is a feeling tone of sadness, generally brought on by a loss disappointment and frustration. 
From the definition above, we can conclude that depression is psychological condition that changes people's feeling and thought. It can be understood that depression is one of human being problem. Depression can affect all kinds of people, young and old, rich and poor, famous and unpopular people. It means everybody can suffer from depression.

\subsection{Symptoms of depression}

Johnson (2018) describes ten major psychological symptoms of depression, they are;

1. Appetite's Change: if one feels depressed, one does not want to eat something or any kinds of food. He loosed his appetite. It usually happens to a woman.

2. Insomnia: a depressed person is hard to sleep. One always thinks about his problem. So, the brain cannot relax, it works all the time.

3. Shinning responsibility, retreating to bed or couch: one will avoid to work or any other activities, which need some responsibilities. One only stays bedroom and tries to forget his problem.

4. Believing no one cares: one will not trust anyone, but himself. One feels that there is no one who cares himself anymore. One isolates himself from other people and environment. One looses the connections with other.

5. Feeling it is impossible to reach God: one feels that the burden is so heavy to bear. One feels that god is not fair to him or her. One thinks that god has left and forgot him or her. One sops to pray to him (God).

6. Living in the past: one remembers that only his pat time when everything is under his control. One does not want to face the fact nowadays.

7. Self-centeredness: one only thinks about himself. He ignores everything and everyone. One does not put attention to other people or what happens in his environment.

8. Lose of hope, believing there is nothing to live for: a depressed person will lose his hopes. One will feel desperate and feel that there is nothing to struggle in his life anymore. There is nothing to do in his life.

9. Losing interest in one surrounding: one does not have spirit with his surroundings. A depressed person ignores everything surround him. He loses their energy to do 
his hobbies or to do any activities of the society. One even ceases to interact with the society.

10. Difficult in making decision: a depressed person hardly makes any decision. Sometimes he will be confused about what he has to do when he must decide something.

While Jiwo (2012) mentions symptoms of depression as following: (1) feeling sad or unhappy; (2)the little things can make him/her frustrated or very annoyed; (3)Loss of interest or pleasure of daily activities that be loved before; (4)Cannot sleep or mostly sleep (sleep on); (5) Loss of sex drive; (6) Changes in appetite can be loss of appetite and become emaciated or may be experiencing increased appetite and obesity; (7) no quite, hard to sit in place; (8) easy to be angry or easy to be offended; (9) thinking slowly, talking slowly and weakly, or moving the body; (10) difficult decision, poor concentration, easily distracted, difficulty remembering; (11) always feeling tired, weak, and lost energy, even a little activity is very hard and spend a lot of energy; (12) feeling worthless, guilty, and always thinking about past failures or mistakes; (13) often think about death or suicide; (14) crying suddenly for no apparent reason; (15) physical disorders that are not obvious cause, such as headaches or back pain.

Next, Andrew et.al (2007) boiled down the diagnosis of depression to just five out of the typical nine symptoms: (1) depressed mood (feelings of sadness or being blue); (2) lack of interest (in activities that you previously enjoyed); (3) feelings of worthlessness; (4) poor concentration; (6) thought of death.

From the above explanation, there are many kinds of symptoms of depression which are described by the experts. The kinds of symptoms become the indicators of analyzing the protagonist's depression in the Moyes' novel Me Before You.

\subsection{Cause of depression}

Causes of depression may be different from one person to the next, especially depending on which type of depression you are experiencing. Generally, may include one or more of the following:

According to Lynne (2009: 3), there is a variety of causes of depression which include: Ioneliness or isolation (loneliness), life experiences pressing (stressful) lately, lack of social support, financial problems, he trauma or abuse in childhood, relationship breakdown, negative mindset, the biological differences (neurotransmitter or hormonal), stressful events in person's life 
Thus, depression can occur as a result of major life changes across the life. These changes may cause feeling of inadequacy and stress. Young people may find it difficult to get a job; they may experience loss a job and as a result of this have financial difficulties such as debt. Younger people may also experience relationship breakdown. Middle age people may experience a variety of loss.

Some examples include the death of parents, children leaving home changes in financial and moving house. An older person may lose their home, their lifelong partner; loss of income due to retirement of may experience moving into long-term care. Many of these life-changing events and experiences can potentially lead to stress and depression.

According to lan H. (2015:56), no one can say for sure what causes depression to develop in a person. For some people, a combination of things may be to blame. For other people, one factor seems most significant. For still other people, depression develops for no apparent reason. Some causes or triggers of depression include changes in brain chemicals. Other causes may be inherited tendencies, emotional shock, stress, illness, or substance use.

\section{Research Method}

The descriptive qualitative method is applied here. Moleong quoted by Purwarno and Suhendi (2018) states that the qualitative research as a research procedure that results descriptive data in written words. Regarding the research method, having a focus on content analysis, qualitative research is used in performing this research. According to Dowson (2002: 14), qualitative research explores attitudes, behavior, and experiences through such method as interviews. He also says that in qualitative research, the write is able to find out, define, describe, and explain the substance of narration. Therefore, the study presents the analysis and findings in the qualitatively descriptive form.

\section{Result and Discussion}

The analysis is divided into two sub topics. They are the symptoms and cause of the protagonist's depression. There are three symptoms of protagonist's depression shown in the novel: believing no one cares, self-centeredness, and committing suicide. Then, the two causes of the protagonist's depression are social cause: loneliness or isolation and psychological cause: trauma. 


\subsection{The symptoms of protagonist's depression}

\subsubsection{Believing no one cares}

The first symptom of protagonist's depression is believing no one cares. The protagonist, Will Traynor, feels that there is no one who cares him anymore. And he isolates himself from other people and environment and looses the connections with other people especially his friend and his family.

No. I want him to live.

But-

But I want him to live if he wants to live."

(Moyes, 2012: 392)

The quotation above shows that Lou wanted Will to stay alive but Will still wants to end his life because he thinks that no one will feel lost after he commits suicide. This is the heart of the issue. Out of their love for Will, his parents and Lou want to keep him alive at all costs, but they do not take into account what Will wants. This is not necessarily to support his decision, but simply to explain it.

...I needed to tell him, silently, that things might change,

grow, or fail, but that life did go on. That we were all

part of some great cycle, some pattern that it was

only God's purpose to understand. I couldn't say that

to him, of course-Will and I have never been

able to say much to each other-but I wanted to show him.

A silent promise, if you like, that there was a bigger picture,

a brighter future."

(Moyes, 2012:184)

The above quotation tells that his mother truly loves him. But he always rejects all the attention of others and he just believes that no one can be trusted. Therefore, he always tries to end his life repeatedly.

The next quotation explains that Will's mother keeps trying to care about him but he refuses his mother's care and even gets angry with what his mother does.

She would ask Will if he wanted anything, 
occasionally suggest something he might like

to do tomorrow - some outing, or some friend

who had asked after him - and he would almost

always answer dismissively, if not with downright

rudeness. (Moyes, 2012: 56)

It is shown that his mother asks various pleasant things about what he wants to do. Unfortunately, Will sometimes answers it with very rude words. This describes that he is never close to his mother. His mother always spends time working, but after the accident happens, his mother changes and wants to pay more attention to him. Again, Will does not believe it and he is always rude to his mother. Will is only being nice to his father, and it sometimes makes her mother feel disappointed.

\subsubsection{Self-centeredness}

Will Traynor only thinks about himself. He ignores everything and everyone. He does not put attention to other people or what happens in his life.

I'm not going to try and change my mind. If you're there,

you accept it's my choice. This is the first thing l've been

in control of since the accident. (Moyes, 2012: 256)

From the quotation above, Will shows only selfishness and refuses to change his mind. Even though Lou wants to help him change his decision and give him a little hope that the illness he suffers from can be cured. But Will still does not accept it and endures its plans to end his life.

.....But I did try. I really tried. For months.

And he just pushed me away.' Her jaw was rigid, her expression oddly furious. 'He actually didn't want me here. He made that very clear.'

.....You know, you can only actually help someone who wants to be helped,' she said.

(Moyes, 2012: 65)

The above quotation shows that Will refuses to accept all the attention of others, especially from Lissa, her ex-girlfriend. After the accident Will seems disappear and 
he only concerns to himself. Although Lissa has tried to get close to Will back, he still refuses her. Even Lissa has tried to maintain communication with Will and tries to approach Will back but all Lissa's efforts are fail. Will still avoids her and he does not receive all the attention from her.

\subsubsection{Committing suicide}

Not all suicide attempts are made someone end in death. Even some can be saved from death. However, despite survived, the perpetrators will try to take their own life because only death is what they want. It also happens to the protagonist, Will Traynor. He keeps trying to commit suicide. Here is to show that.

...his head lolling by his armrest, a sea of dark, sticky blood pooling around his wheels. He had located a rusty nail, barely half an inch emerging from some hurriedly finished woodwork in the back lobby, and, pressing his wrist against it, had reversed backwards and forwards until his flesh was sliced to ribbons.

(Moyes, 2012: 141-142)

The quotation shows that Will Traynor tries to commit suicide but fails because it is known by his housemaid. Will fail to commit suicide and he is immediately rushed to the hospital. But Will's attempt to commit suicide does not stop. Finally, Will decides to join Dignitas group. Dignitas is a group in which there are people who want to end their lives because of various problems of life.

The other supported quotation above tells about the symptoms of protagonist's depression that to commit suicide can be shown in the following quotation:

This is not the life I chose. There is no prospect of my recovery, hence it is a perfectly reasonable request to ask to end it in a manner I see fit.

(Moyes, 2012: 140)

It tells that his decision to end his life is simple. He cannot live without hope for recovery. Suicide is an awful thing, and he never wants other people to ban him to do so because he has decided truly to end his life.

According to the information from the quotation above, it can be explained Will truly wants to end his life and does not change his plan.

I realized I was afraid of living without him. 


\section{How is it you have the right to destroy my life,}

I wanted to demand of him,

\section{but I'm not allowed a say in yours?}

But I had promised. (Moyes, 2012: 462)

From the quotation above, it is shown that Will want to die is the hardest thing that Lou has ever faced in her life, but it proves the extent of her love for him. Obviously she hopes him choose to live. Obviously she had rather that they spend the rest of their lives together. But she knows Will well enough to know that he will not waver in his decision, and she chooses to support him as best she can through this difficult time.

\subsection{The cause of protagonist's depression}

\subsubsection{Social cause: Loneliness or isolation}

The first cause of the protagonist's depression is loneliness or isolation with the circumstances that have occurred. Will Traynor is not confident to meet his friends and finally decides to avoid the outside environment. That finally makes him feel isolated. He does not want to meet others.

.....in those moments when I glimpsed him staring

out of the window. And as the days went by and I realized

that his condition was not just a matter of being stuck in

that chair, of the loss of physical freedom, but a

never-ending litany of indignities and health problems,

of risks and discomforts, I decided that if I were Will,

I would probably be pretty miserable too.

(Moyes, 2012: 124)

From the quotation above, it can be seen that Lou thinks that Will only isolates himself in the room without doing anything. The only thing he can do is daydream of thinking about everything happening to him.

And there was no way I could carry on with my job

'No. Nor the apartment, the holidays, the life ...

I believe you met my ex-girlfriend.' The break in his 
voice couldn't disguise the bitterness. 'But I

should apparently be grateful, as for some time they

didn't think I was going to live at all.

(Moyes, 2012: 106)

The quotation shows that Will intentionally becomes far from his ex-girlfriend because he does not want anyone to know his relationship. So he chooses to be alone and to be isolated from his ex-girlfriend and his friend.

What Will feels is seen by Lou. Lou understands that Will prefers being isolated due to his physical condition which makes him disable to do what everything he does usually. The following quotation shows what Lou sees from Will's condition.

.....And as the days went by and realized that

his condition was not just a matter of being

stuck in that chair, of the loss of physical freedom,

but a never-ending litany of indignities and

health problems, of risks and discomforts,

I decided that if I were Will, I would probably be

pretty miserable too. (Moyes, 2012: 57)

That shows Lou will commit what Will has done. And, according to Lou, it will make Will feel miserable and want to be isolated from others.

\subsubsection{Psychological cause: Trauma}

Will Traynor has got a very severe accident and finally he becomes paralyzed and can only be in a wheelchair without being able to carry out any activities. Such Trauma experienced by Will creates a huge impact on him; therefore, he wants to carry out repeated suicide attempts. Not only does he try to kill but also suffers from very acute depression until he has to isolate himself from social life and it makes him lose everything. Life that is originally very perfect suddenly changes dramatically after the accident. The accident has changed his whole life.

When I nodded, he closed his eyes again. 'Motorbike accident.

Not mine. I was an innocent pedestrian.'I thought it would

be skiing or bungee jumping or something.' 'Everyone does. 
God's little joke. I was crossing the road outside my home.

Not this place,' he said. 'My London home.'

(Moyes, 2012:105-106)

The above quotation tells that Will tells Lou that the accident continues to shadow him. Because of the accident, he cannot continue his life. He continues to be in a wheelchair. Will also cannot do anything he likes anymore because of the physical limitations he experiences now. Will experiences quite heavy trauma so he thinks his life has no meaning anymore.

I get really, really scared of how this is going to go [...]

I could end up not being able to breathe by myself,

not being able to talk.

(Moyes, 2012: 237)

Based on the quotation above, Will feels so depressed on his condition. It is bad enough that he loses his independence and ability to do the things he loves, but he also has to face the prospect, that is, it is only going to get worse.

I don't do anything, Miss Clark.

I can't do anything anymore but sit.

I just about exist."

(Moyes, 2012: 122)

The trauma experienced by Will makes him find trouble to accept his spinal injury because it removes his ability to do the things he once enjoys. It can be imagined if you could never do any of your favorite hobbies ever again. That will be miserable and traumatic.

Based on the data collected and analyzed from the novel, the findings of analysis are:

1. There are three symptoms of the protagonist's depression. Those are believing no one cares, self-centeredness, and committing suicide. These symptoms indicate that the protagonist really suffers from depression. It is shown that the protagonist believes no one cares about his condition. Then, he just focuses on his own problem that he thinks he is the only one who has unsolved problem. Finally, he wants to end his life. 
2. The main causes of the protagonist's depression are feeling isolated and trauma. Because of the accident he experienced, he is unable to do all the things he wants again. This accident leaves trauma to him and finally he feels isolated because of his disability.

\section{Conclusion}

All the data that have been collected from Moyes' novel Me Before you have been analyzed in detail in the above sub topic. It comes to a conclusion that depression sometimes can cause people to commit suicide. In this novel, the protagonist tries to commit suicide because he has been diagnosed that he gets depressed, and it is known through the symptoms shown by him in the novel. He gets depressed because the accident leaves him quadriplegic and makes him traumatic and feels isolated from many people especially his family and friends.

\section{References}

[1] Andrews et al. (Dec $1^{\text {st }}$, 2007). Issues for DSM-V: simplifying DSM-IV to enhance utility: the case of major depressive disorder. The American Journal of Psychiatry,164,17841785. http://doi.org/10.1176/appi.ajp.2007.07060982

[2] Berstain, Douglas. (1988). Psychology. London: Indiana University Press.

[3] Downing-Orr, Kristina. (2013). Rethinking depression why current treatment fail language of science. New York: Springer Science \& Business Media

[4] Dowson, Richard. (2002). The research project. California: Art and Gart Publising Company

[5] Goodman, C Catherine. (2011). Depression: clinical guide. Rome: Kent Publishing Company

[6] Ian H, Gotlib, Constance L. Hammen. (2015). Handbook of depression. London: Guilford Publication

[7] Jiwo, Tirto. (2012). Depresi: panduan bagi pasien, keluarga dan teman dekat. purworejo: Pusat Pemulihan dan Pelatihan Bagi Penderita Gangguan Jiwa.

[8] Johnson, D.A.W. (Jan $2^{\text {nd }}, 2018$ ). The significance of depression in the prediction of relapse in chronic schizophrenia. The British Journal of Psychhiatry,152(3),320-323. http://doi.org/10.1192/bjp.152.3.320

[9] Lynne, Walsh. (2009). Depression care across the lifespan willey online library: books. London. John Willey \& Sons 
[10] Moyes, Jojo. (2012). Me before you. Britain: Penguin Books.

[11] Purwarno \& Suhendi, A. (2018). Minangkabau's Marriage and Delik Adat Laws in Abdulkarim Khiratullah's Mencari Cinta Yang Hilang. KnE Social Sciences, 3(4), 708-. https://doi.org/10.18502/kss.v3i4.1979

[12] Veranita, Desi. (July $16^{\text {th }}, 2013$ ). Major depression reflected in jodie foster's the beaver movie (2011): a psychoanalytic approach. Journal_Publication. Universitas Muhammadiyah Surakarta. Retrieved from http://eprints.ums.ac.id/id/eprint/24845 